\title{
Constraints faced by the dairy farmers in management of their dairy enterprises
}

\author{
B.L. PISURE, B.M. THOMBRE AND V.N. SIDAM
}

\begin{abstract}
Dairy enterprise, next to agriculture, not only provides continuous income and improves dietary standards of family, but also supplements the income and reduces unemployment to a large number of the rural people. This study was conducted to study the various constraints faced by these dairy farmers while managing their enterprise. The study was conducted in Latur district of Maharashtra state. Two tahsils and four villages from each tahsil were selected randomly. Fifteen dairy farmers from eight villages were selected to comprise a sample of 120 respondents. The multistage random sampling was used to select district, tahsil, village and dairy farmers. The respondents were personally interviewed and the data collected were processed and statistically analyzed by using statistical techniques like frequency and percentage. During research it was found that, lack of storage facilities for milk, high cost of concentrates and distant location of Artificial Insemination Centers are three major constraints to the dairy farmers in management of their dairy enterprise.
\end{abstract}

KEY WORDS : Constraints, Dairy farmers, Management, Dairy enterprises

HOW TO CITE THIS PAPER : Pisure, B.L., Thombre, B.M. and Sidam, V.N. (2015). Constraints faced by the dairy farmers in management of their dairy enterprises. Res. J. Animal Hus. \& Dairy Sci., 6(1) : 76-78.

Address for correspondence :

B.L. Pisure, Department of Extension Education, College of Agriculture, Vasantrao Naik Marathwada Krishi Vidyapeeth, PARBHANI (M.S.) INDIA

Email : blpisure11@gmail.com,braj_agri@rediffmail.com

Associated Authors' :

B.M. Thombre, College of Agriculture (VNMKV) LATUR (M.S.) INDIA

V.N. Sidam, Department of Extension Education, College of Agriculture, Vasantrao Naik Marathwada Krishi Vidyapeeth, PARBHANI (M.S.) INDIA 